\title{
Teknik Restrukturisasi Kognitif untuk Menurunkan Mogok Sekolah pada Siswa SMP
}

\author{
Devy Probowati \\ Universitas Negeri Malang, Jawa Timur, Indonesia \\ devy.probowati.fip@um.ac.id \\ Triyono \\ Universitas Negeri Malang, Jawa Timur, Indonesia \\ triyono.fip@um.ac.id \\ Carolina Ligya Radjah \\ Universitas Negeri Malang, Jawa Timur, Indonesia \\ Corlina.ligya.fip@um.ac.id
}

\begin{abstract}
Abstrak
Penelitian ini bertujuan untuk mengamati teknik restrukturisasi kognitif dalam menurunkan mogok sekolah siswa SMP. Penelitian ini menggunakan metode eksperimen melaui enam tahapan menggunakan rancangan single subject design dengan bentuk rancangan A-B-A. Fase baseline (A) dilakukan selama tiga sesi, fase intervensi (B) dilakukan selama enam sesi, dan fase baseline ( $\left.A^{\prime}\right)$ dilakukan selama tiga sesi. Hasil penelitian menunjukkan bahwa pada fase baseline (A) masing-masing subjek masih berada pada kondisi yang sama, fase intervensi (B) masing-masing subjek berada pada kondisi yang sudah stabil, dan fase baseline ( $A^{\prime}$ ) masing-masing subjek sudah menunjukkan perbedaan. Oleh karena itu, dapat disimpulkan bahwa terdapat perbedaan dari sebelum diberikan intervensi dengan sesudah diberikan intervensi menggunakan teknik restrukturisasi kognitif untuk menurunkan mogok sekolah siswa SMP dengan kategori penurunan tingkat mogok sekolah setiap subjek berbeda-beda.
\end{abstract}

Kata kunci: teknik restrukturisasi kognitif, mogok, sekolah 


\begin{abstract}
Cognitive Restructuring Techniques to Reduce School Strikes in Middle School Students. This study aims to observe cognitive restructuring techniques in reducing junior high school strike students. This study uses an experimental method through six stages using a single subject design with $A-B-A$ design. The baseline phase (A) was carried out for three sessions, the intervention phase (B) was carried out for six sessions, and the baseline phase (A ') was carried out for three sessions. The results showed that in the baseline phase (A) each subject was still in the same condition, the intervention phase (B) of each subject was in a stable condition, and the baseline phase (A ') of each subject had shown difference. Therefore, it can be concluded that there is a difference from before being given an intervention to after being given an intervention using cognitive restructuring techniques to reduce school strikes of junior high school students with the category of reducing the level of school strike each subject is different.
\end{abstract}

Keywords: Cognitive Restructuring Techniques, Strike, School

\title{
A. Pendahuluan
}

Sekolah merupakan tempat untuk mengenyam pendidikan formal. Pendidikan formal bertujuan untuk mengajarkan disiplin ilmu pengetahuan dan membangun karakter sehingga siswa diharapkan dapat memunculkan perilaku yang sesuai dengan nilai dan norma di masyarakat. Salah satu jenjang pada pendidikan formal adalah sekolah menengah pertama. Siswa SMP umumnya berada pada rentang usia 13-15 tahun. Usia sekolah tersebut sedang melewati masa transisi yaitu dari anak-anak menuju remaja. Hurlock (2000) menyatakan bahwa masa perpindahan atau masa transisi inilah rentan terjadi emosi yang tak terkendali. Diperkuat kembali pernyataan Chomariah (2008) bahwa semua aspek kehidupan pada usia ini akan berkembang, seperti perkembangan fisik, seksual, psikologi, sosio-emosional, kognitif, serta moral.

Siswa SMP yang telah memasuki masa remaja diharapkan memiliki kematangan emosi, sehingga dapat memberikan reaksi emosional yang stabil. Keadaan emosi yang stabil dan adanya keterbukaan untuk menceritakan 
permasalahan yang terjadi dapat membawa dampak baik bagi remaja di lingkungan dimanapun ia berada, yaitu salah satunya adalah lingkungan sekolah. Harapannya siswa dapat beradaptasi di lingkungan sekolah dan mampu menyelesaikan permasalahan yang ia hadapi di sekolah.

Salah satu permasalahan yang sering terjadi di kalangan siswa adalah ketidakinginan untuk berada di lingkungan sekolah. Kurangnya kemampuan siswa dalam menghadapi berbagai situasi dan permasalahan di sekolah, mengakibatkan siswa yang hendak pergi ke sekolah membawa beban-beban emosional tertentu seperti perasaan cemas atau takut yang berpotensi untuk menghalangi siswa berangkat ke sekolah. Beban-beban emosional tersebut jika dibiarkan akan menimbulkan beberapa tingkah laku yang tidak normal yaitu salah satunya adalah mogok sekolah atau dalam bahasa asing biasa disebut dengan school refusal.

Mogok sekolah yaitu masalah emosional yang dimanifestasikan dengan ketidakinginan siswa untuk menghadiri sekolah dengan menunjukkan simptom fisik, yang disebabkan kecemasan berpisah dari orang terdekat, pengalaman negatif di sekolah atau mempunyai masalah dalam keluarga. Mogok sekolah juga disebabkan karena siswa tidak memiliki motivasi untuk pergi ke sekolah (Kearney, Chapman, and Cook 2005). Siswa yang mengalami mogok sekolah merasa tidak nyaman yang disebabkan adanya perasaan cemas terhadap sesuatu yang berkaitan dengan sekolah sehingga mereka dapat kehilangan kemampuan untuk menguasai tugas-tugas perkembangan (Davison, John, and Ann 2006).

Siswa menunjukkan mogok sekolah dengan seringnya siswa tersebut tidak masuk sekolah padahal pagi harinya siswa berpamitan untuk pergi ke sekolah namun kenyataannya siswa tersebut tidak sampai di sekolah karena ia merasa ada sesuatu yang lebih menarik atau menyenangkan daripada harus datang ke sekolah. Terdapat pula siswa yang mau pergi ke sekolah setelah mendapat teguran dari orang tua, sehingga hal itu dilakukannya secara terpaksa. Bahkan siswa tersebut mempunyai tekanan dan membawa beban tersendiri untuk pergi ke sekolah karena adanya permasalahan di lingkungan sekolah yang tidak dapat ia selesaikan 
dan tentunya siswa cenderung akan menghindari permasalahan yang dihadapinya tersebut (Kearney and Albano 2007).

Fakta berdasarkan hasil studi pendahuluan yang dilakukan peneliti di beberapa SMP Kota Malang yaitu SMP Negeri 5, SMP Negeri 7, dan SMP Negeri 13 dengan menggunakan subyek kelas tujuh dan delapan, diperoleh hasil yaitu sebesar 10,27\% siswa mengalami mogok sekolah dengan kategori tinggi, 52,97\% siswa mengalami mogok sekolah dengan kategori sedang, dan 36,75\% siswa mengalami mogok sekolah dengan kategori rendah. Studi pendahuluan mengenai mogok sekolah pada siswa SMP juga dapat dilihat dari empat indikator, di mana sebanyak 31,59\% siswa SMP memperoleh tangible reinforcement yang dianggap nyata atau tampak di luar sekolah, 25,90\% siswa SMP memperoleh perhatian dari orang lain (significant others) yang dianggap penting dalam kehidupannya, 24,45\% siswa SMP menghindari stimulus di sekolah yang dapat memunculkan rasa cemas dan depresi (menimbulkan efek negatif), dan 18,04\% siswa SMP menghindari situasi sosial (seperti permusuhan) di sekolah.

Peneliti juga melihat fenomena adanya mogok sekolah pada saat kegiatan Pengalaman Praktik Lapangan yang dilakukan pada bulan Agustus-Oktober 2014 di SMP Negeri 20 Malang. Fenomena di lapangan yang ditemukan peneliti adalah salah satu siswa di kelas 8 yang menjadi kelas binaan peneliti sering tidak masuk sekolah. Beberapa hari siswa tersebut tidak masuk sekolah karena sakit, namun hal ini terjadi secara berlanjut bahkan siswa tersebut tidak masuk sekolah tanpa surat keterangan. Berdasarkan hasil wawancara peneliti kepada siswa yang bersangkutan mengungkapkan jika ia tidak dapat beradaptasi dengan teman sekelas. Bahkan beberapa teman sekelas tersebut menjauhinya, sehingga hal tersebut mengakibatkan ia enggan untuk pergi ke sekolah. Diperkuat kembali ketika ia mendapatkan nilai ulangan matematika yaitu 40 yang merupakan nilai paling rendah di kelas. Siswa tersebut mengungkapkan bahwa ia merasa sangat malu dan putus asa. Dengan kejadian tersebut mengakibatkan ia menjadi lebih enggan untuk berangkat sekolah dan memilih berada di rumah saja karena ia 
merasa di rumah lebih nyaman tanpa adanya rasa malu dan takut seperti yang ia rasakan di sekolah.

Penelitian Setzer \& Salzhauer (2006) menunjukkan persentase kejadian mogok sekolah secara Internasional adalah 2,4\%. Selain itu diungkapkan pula bahwa di Amerika persentase kejadian kasus mogok sekolah sebesar 1,3\% pada siswa berusia 14-16 tahun dan 4,1\%-4,7\% pada siswa berusia 7-14 tahun. Penelitian Ampuni \& Andayani (2007) menyatakan bahwa mogok sekolah dipengaruhi salah satunya oleh struktur kepribadian pada aspek emosi dan sosial yang ditandai rendahnya harga diri, kurangnya kemandirian dan tanggung jawab, serta kurangnya kemampuan sosial. Sementara itu penelitian yang dilakukan oleh Charlina (2013) di salah satu SMP Kota Batu, menunjukkan bahwa pada kelas 7 sebanyak 65,7\% mengaku keluar saat guru tidak datang mengajar dan pada kelas 8 sebanyak 73,9\% mengaku tidak masuk sekolah tanpa keterangan. Hasil penelitian Suseno (2015) menyebutkan bahwa mogok sekolah tidak terlepas dari faktor internal dan eksternal. Faktor internal yang mempengaruhi perilaku mogok sekolah antara lain adanya ancaman yang dilakukan oleh siswa agar apa yang ia minta dapat terpenuhi, adanya kekecewaan yang amat mendalam terhadap sesuatu, dan mengalami kesulitan pada beberapa pelajaran. Faktor eksternal yang mempengaruhi terjadinya perilaku mogok sekolah antara lain sering menerima ejekan dari teman ketika berada di sekolah, dan adanya perilaku lekat yang berlebihan dengan orangtua.

Hasil studi pendahuluan yang telah dilakukan oleh peneliti, serta beberapa hasil penelitian terdahulu mengenai mogok sekolah, dapat dikatakan bahwa mogok sekolah merupakan salah satu permasalahan dalam bidang pendidikan yang sangat penting untuk diperhatikan dan ditangani. Penanganan mogok sekolah ini perlu adanya kerjasama yang baik dari beberapa pihak seperti orangtua, guru mata pelajaran, wali kelas, dan juga guru bimbingan dan konseling. Kerjasama ini dilakukan agar penyebab dari perilaku mogok sekolah dapat diketahui dan orangtua perlu untuk memberi dukungan, motivasi, atau penguatan kepada siswa 
untuk tetap pergi ke sekolah. Pendekatan yang dapat digunakan untuk menangani perilaku mogok sekolah antara lain adalah Cognitive Behavioral Therapy (Brill 2009), dimana pendekatan ini bertujuan untuk mengubah pemikiran irasional mengenai sekolah menjadi lebih adaptif. Oleh karena itu, yang menjadi problem adalah bagaimana teknik restrukturisasi kognitif dalam menurunkan mogok sekolah siswa SMP

\section{B. Pembahasan}

\section{Teknik restrukturisasi kognitif}

Cognitive behavioral therapy melibatkan kognitif dan perilaku. Konseling dengan intervensi kognitif akan membantu individu dengan menggunakan akalnya untuk berpikir tentang hal-hal yang menyebabkan munculnya permasalahan. Konseling dengan intervensi perilaku membantu individu belajar mengubah perilaku, menenangkan pikiran dan fisik sehingga merasa lebih baik. Penerapan intervensi ini bagi siswa yang mengalami mogok sekolah harapannya dapat berpikir tentang hal yang menyebabkan permasalahan, kemudian pikiran-pikiran tersebut dapat diorganisasikan kembali menjadi pikiran dan pernyataan diri positif, sehingga perilaku yang dimunculkan dan diperlihatkan adalah perilaku positif. Salah satu teknik dalam cognitive behavioral therapy adalah restrukturisasi kognitif.

Teknik restrukturisasi kognitif mengidentifikasi gangguan emosional dengan mencari emosi negatif, pikiran otomatis, dan keyakinan utama (Bond and Dryden 2004). Teknik restrukturisasi kognitif, memusatkan perhatian pada upaya mengidentifikasi dan mengubah pikiran-pikiran disfungsional atau pernyataan diri negative menjadi pikiran baru yang lebih rasional dan adaptif, yang berpengaruh terhadap tingkah laku lebih rasional pula (Cormier and Nurius 2009). Senada dengan cognitive behavioral therapy, pada teknik ini berusaha untuk mengubah pikiran-pikiran negatif pada siswa yang mengalami mogok sekolah, sehingga ketika pikiran negatif atau disfungsional sudah menjadi pikiran yang rasional 
maka perilaku bersekolah pada siswa akan meningkat serta siswa akan merasa bahagia dan nyaman ketika berada di sekolah.

Beberapa penelitian mengenai penggunaan teknik restrukturisasi kognitif pernah dilakukan, diantaranya adalah penelitian oleh Muthmainah (2012) menggunakan teknik restrukturisasi kognitif untuk menurunkan Negative Automatic Thoughts. Hasil penelitiannya menunjukkan bahwa teknik restrukturisasi kognitif efektif untuk menurunkan Negative Automatic Thoughts. Saputra (2015) juga menggunakan teknik restrukturisasi kognitif untuk menangani prokrastinasi akademik siswa SMK, hasil penelitian ini juga menyebutkan bahwa restrukturisasi kognitif dapat mengurangi prokrastinasi akademik.

Berdasarkan seluruh paparan di atas, secara teoritis dapat diperoleh makna bahwa teknik restrukturisasi kognitif dapat membantu permasalahan siswa. Sejauh ini, belum terdapat penelitian yang secara spesifik membuktikan bahwa teknik restrukturisasi kognitif efektif untuk menurunkan mogok sekolah pada siswa. Oleh sebab itu, peneliti memandang perlu untuk mengujicobakan teknik restrukturisasi kognitif sebagai salah satu alternatif bantuan dalam menangani permasalahan mogok sekolah siswa SMP.

\section{Metode}

Penelitian ini menggunakan rancangan penelitian eksperimen dengan desain subjek tunggal (single subject). Rancangan single subject design ini dipilih karena subjek penelitian bersifat individual. Rancangan subjek tunggal juga memberikan kesempatan kepada peneliti untuk memaparkan lebih detail tentang perubahan-perubahan yang dihasilkan pada sesi konseling. Sukmadinata (2005) mengemukakan bahwa pendekatan dasar dalam eksperimen subjek tunggal adalah meneliti individu dalam kondisi tanpa perlakuan dan kemudian dengan perlakuan sehingga akibatnya terhadap variabel dapat diukur dalam kedua kondisi tersebut. 
Desain rancangan subjek tunggal yang digunakan dalam penelitian ini adalah A-BA.

Pada desain ini, fase A melambangkan kondisi baseline dan B melambangkan kondisi perlakuan atau intervensi, dan A kedua melambangkan kondisi pasca intervensi dihilangkan. Fase baseline (A') dimaksudkan sebagai kontrol untuk fase intervensi, sehingga memungkinkan untuk menarik kesimpulan bahwa adanya hubungan fungsional antara teknik restrukturisasi kognitif dengan mogok sekolah. Oleh karena itu, dapat diperoleh hasil yang menjelaskan bahwa penurunan mogok sekolah disebabkan karena adanya intervensi yang telah diberikan dan bukan dari faktor lain. Bentuk rancangan penelitian A-B-A dapat dilihat pada gambar berikut.

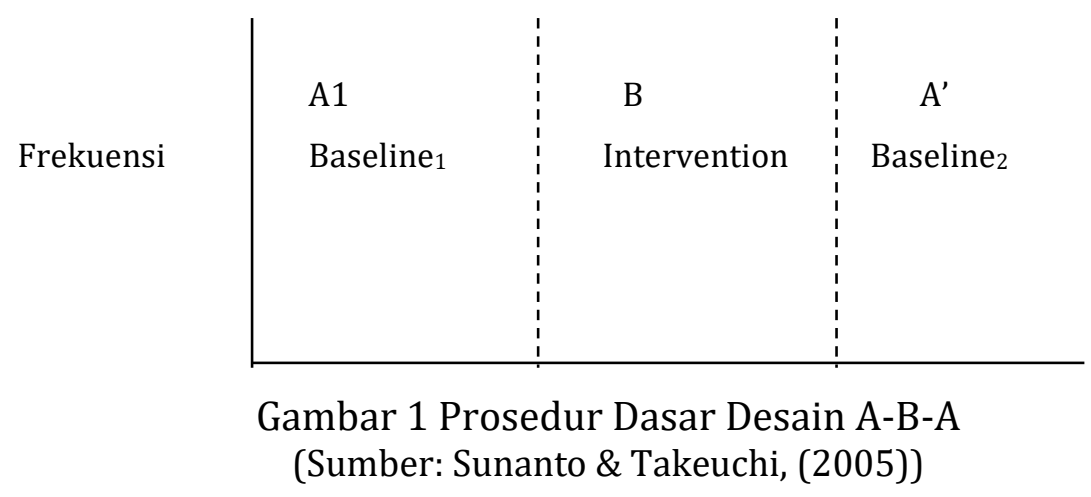

Subjek dalam penelitian ini adalah siswa SMP Negeri 20 Malang kelas VIII pada tahun ajaran 2016/2017 yang diidentifikasi mengalami mogok sekolah tinggi. Pemilihan subjek penelitian ini berdasarkan fenomena yang ditemukan peneliti pada siswa kelas VIII yang beberapa kali tidak masuk sekolah dengan alasan malu karena siswa tersebut mendapat nilai ulangan matematika terendah di kelas. Subjek penelitian juga ditentukan melalui penjaringan skala mogok sekolah yang didukung dengan penggunaan hasil wawancara, observasi, konsultasi dengan guru BK, serta saran dari guru dan wali kelas. Berdasarkan data yang diperoleh dari penjaringan skala mogok sekolah, terdapat 5 siswa dengan kategori tinggi yang menjadi subjek penelitian, yaitu AB, FN, SW, DE, dan RF. 
Penelitian ini menggunakan dua jenis instrumen yaitu (1) bahan perlakuan berupa panduan pelaksanaan teknik restrukturisasi kognitif untuk menurunkan mogok sekolah serta skala mogok sekolah (2) instrumen pengumpulan data yang terdiri dari skala mogok sekolah, lembar observasi mogok sekolah, pedoman wawancara, dan lembar tugas. Sebelum instrumen bahan perlakuan dan pengumpulan data digunakan dalam penelitian di lapangan, terlebih dahulu dilakukan penilaian dari uji ahli. Penilaian dari ahli bertujuan untuk mengetahui kekurangan pada bahan perlakuan secara teoritis, selain itu juga untuk menetapkan akseptabilitas dari skala mogok sekolah. Penilaian ahli diberikan kepada dua orang dosen Universitas Negeri Malang di bidang Bimbingan dan Konseling yang bergelar Doktor. Analisis yang digunakan dalam penilaian uji ahli ini adalah model kesepakatan (Inter-rater Agreement Model). Berdasarkan hasil penilaian ahli menunjukkan bahwa panduan teknik restrukturisasi kognitif telah layak untuk dipergunakan dalam proses intervensi.

Prosedur penelitian ini dilaksanakan melalui tiga tahapan yaitu persiapan, pelaksanaan, dan akhir. Pada tahap persiapan kegiatan yang dilakukan adalah (1) menyusun dan merevisi bahan perlakuan; (2) uji coba instrumen; (3) ijin penelitian; dan (4) menentukan subjek penelitian. Pada tahap pelaksanaan kegiatan yang dilakukan adalah (1) melaksanakan fase baseline (A) yang pertama melakukan asesmen untuk menentukan gambaran tingkat mogok sekolah sebelum diberikan intervensi, yang kedua mengevaluasi frekuensi munculnya perilaku mogok sekolah. (2) fase intervensi (B) yang dilaksanakan dengan enam tahapan teknik restrukturisasi kognitif. (3) pengukuran fase baseline ( $\mathrm{A}^{\prime}$ ). Adapun tahap akhir dalam penelitian ini adalah melakukan analisis data serta penulisan laporan hasil penelitian.

Penelitian ini menggunakan analisis data berupa analisis visual grafik dan analisis statistik. Analisis visual grafik dilakukan dengan metode split middle (Sunanto, 2005). Analisis visual mencakup analisis dalam kondisi dan analisis antar kondisi. Terdapat enam komponen analisis dalam kondisi, yaitu (1) panjang 
kondisi; (2) estimasi kecenderungan arah; (3) kecenderungan stabilitas; (4) jejak data; (5) level stabilitas dan rentang; dan (6) level perubahan. Pada analisis antar kondisi mencakup (1) jumlah variabel yang diubah; (2) perubahan kecenderungan dan efeknya; (3) perubahan stabilitas; (4) perubahan level; dan (5) data overlap. Kriteria stabilitas yang ditunjukkan oleh angka sebesar 75\% - 100\% stabil: <75\% bervariasi (Runtukahu 2013). Sedangkan Kriteria data tumpang tindih adalah kurang dari 10\% menyatakan intervensi sangat efektif, 10\%-25\% menyatakan efektif, 25\%-50\% menyatakan intervensi dipertanyakan, dan lebih dari 50\% menyatakan intervensi tidak efektif. Analisis statistik dilakukan dengan uji wilcoxon matched-pairs signed-ranks test, analisis ini yaitu hasil dari pre-test dan post-test dianalisis secara statistik untuk melihat signifikansi perubahan antara sebelum dan sesudah intervensi. Analisis statistik ini menghasilkan nilai Asymp. Sig (2-tailed) atas uji wilcoxon signed ranks test. Nilai Asymp. Sig (2-tailed) yang nantinya akan digunakan dalam uji hipotesis untuk dibandingkan dengan alpha $(\alpha)$ guna menentukan diterima atau ditolaknya sebuah hipotesis. Kriteria pengujiannya adalah (a) Asymp. Sig. (2-tailed) $>\alpha=0,05$ maka Ho diterima, yang artinya teknik restrukturisasi kognitif tidak efektif untuk menurunkan mogok sekolah siswa SMP; (b) Asymp. Sig (2-tailed) $\leq \alpha=0,05$ maka Ho ditolak, yang artinya teknik restrukturisasi kognitif efektif untuk menurunkan mogok sekolah siswa SMP.

\section{Hasil Penelitian}

Penelitian ini melibatkan 5 subjek dari kelas VIII SMP Negeri 20 Malang yang telah terjaring dan terindentifikasi mengalami mogok sekolah tinggi yaitu $A B$, FN, SW, DE, dan RF. Pengukuran dan intervensi untuk menurunkan mogok sekolah dilakukan dalam tiga fase, yaitu fase baseline (A) yang dilakukan sebanyak tiga sesi, fase intervensi (B) yang dilakukan sebanyak enam sesi, dan fase baseline (A') yang dilakukan sebanyak tiga sesi. Analisis yang dilakukan adalah (1) analisis individu; (2) analisis kelompok; dan (3) analisis statistik. Analisis individu 
bertujuan untuk melihat perkembangan masing-masing subjek penelitian. Adapun hasil dari pengukuran observasi kelima subjek penelitian selama fase baseline (A), fase intervensi (B), dan fase baseline (A') adalah sebagai berikut:

Tabel 1 Hasil Pengukuran Observasi Mogok Sekolah Masing-Masing Subjek

\begin{tabular}{|c|c|c|c|c|c|c|c|c|c|c|c|c|c|}
\hline \multirow[b]{2}{*}{ No } & \multirow[b]{2}{*}{$\begin{array}{c}\text { Konsel } \\
\text { i }\end{array}$} & \multicolumn{3}{|c|}{$\begin{array}{c}\text { Fase } \\
\text { Baseline (A1 }\end{array}$} & \multicolumn{6}{|c|}{ Fase Intervensi (B) } & \multicolumn{3}{|c|}{$\begin{array}{c}\text { Fase } \\
\text { Baseline }\left(A^{\prime}\right)\end{array}$} \\
\hline & & $\begin{array}{c}\text { Se } \\
\text { si } \\
1\end{array}$ & $\begin{array}{c}\text { Se } \\
\text { si } \\
2\end{array}$ & $\begin{array}{c}\text { Se } \\
\text { si } \\
3\end{array}$ & $\begin{array}{l}\text { Se } \\
\text { si } \\
1\end{array}$ & $\begin{array}{l}\text { Se } \\
\text { si } \\
2\end{array}$ & $\begin{array}{l}\text { Se } \\
\text { si } \\
3\end{array}$ & $\begin{array}{l}\text { Se } \\
\text { si } \\
4\end{array}$ & $\begin{array}{c}\text { Se } \\
\text { si } \\
5\end{array}$ & $\begin{array}{l}\text { Se } \\
\text { si } \\
6\end{array}$ & $\begin{array}{c}\text { Se } \\
\text { si } \\
1\end{array}$ & $\begin{array}{c}\text { Se } \\
\text { si } \\
2\end{array}$ & $\begin{array}{l}\text { Se } \\
\text { si } \\
3\end{array}$ \\
\hline 1 & $\mathrm{AB}$ & 54 & 54 & 53 & 49 & 46 & 42 & 38 & 36 & 35 & 24 & 19 & 18 \\
\hline 2 & FN & 54 & 54 & 53 & 48 & 46 & 41 & 38 & 37 & 34 & 27 & 23 & 20 \\
\hline 3 & SW & 54 & 54 & 51 & 46 & 43 & 38 & 37 & 36 & 33 & 25 & 21 & 19 \\
\hline 4 & $\mathrm{DE}$ & 54 & 54 & 53 & 46 & 41 & 38 & 37 & 36 & 35 & 27 & 23 & 20 \\
\hline 5 & $\mathrm{RF}$ & 54 & 54 & 54 & 49 & 45 & 41 & 37 & 36 & 35 & 24 & 20 & 18 \\
\hline
\end{tabular}

Hasil observasi dari masing-masing subjek dalam table di atas akan digambarkan dalam bentuk grafik dan dianalisis dengan metode split middle.

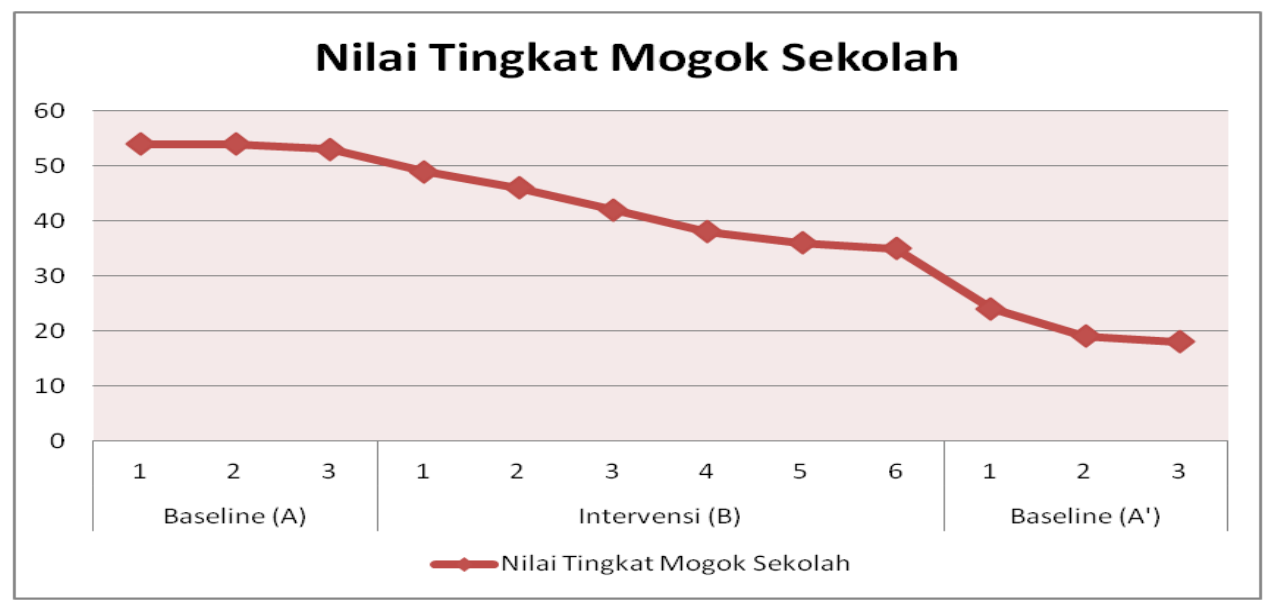

Gambar 2 Grafik Perkembangan Tingkat Mogok Sekolah Subjek AB

AB adalah siswa SMP Negeri 20 Malang yang merupakan subjek pertama dalam penelitian ini yang mengalami mogok sekolah berdasarkan hasil pengukuran awal (pre-test) dengan menggunakan skala mogok sekolah. Hasil wawancara juga menyebutkan bahwa $\mathrm{AB}$ berasal dari keluarga broken home. Ia tinggal bersama ibu, saudara dari ibu, dan juga nenek. Sehari-hari ia berangkat ke 
sekolah diantar oleh pamannya, dan tak jarang ketika AB sudah tiba di sekolah, ia hanya masuk gerbang sekolah kemudian setelah pamannya pergi, ia akan keluar. Dari pengakuan $\mathrm{AB}$ tersebut, ia mengatakan sering tidak masuk sekolah dan lebih memilih untuk bermain game online. AB juga menyebutkan bahwa alasan ia berperilaku demikian karena $\mathrm{AB}$ merasa banyak pikiran sehingga menyebabkan kegiatan sekolah terganggu termasuk terbengkalainya tugas-tugas sekolah. Oleh karena itu, $\mathrm{AB}$ memilih untuk tidak masuk sekolah karena ia berpikir jika nanti dimarahi guru karena tidak mengerjakan tugas, selain itu berdasarkan penuturannya ia mengatakan bahwa muncul pemikiran untuk apa sekolah sedangkan ia lebih senang bermain di luar sekolah.

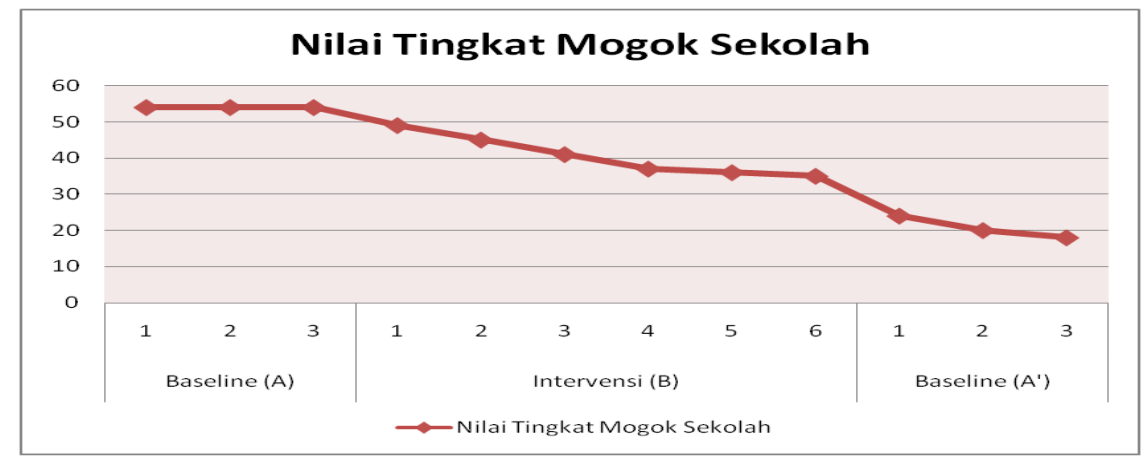

Berdasarkan gambar di atas dapat diketahui bahwa fase baseline (A) dilakukan selama tiga sesi, fase intervensi (B) dilakukan selama enam sesi, dan fase baseline (A') dilakukan selama tiga sesi. Pada fase baseline (A) diperoleh nilai mogok sekolah yang masih stabil antara sesi pertama dan kedua dan mengalami trend menurun pada sesi ketiga. Pada fase intervensi (B) diperoleh nilai mogok sekolah yang mengalami trend menurun dari sesi pertama sampai sesi keenam. Analisis dalam kondisi menyebutkan pada fase baseline ( $\left.\mathrm{A}^{\prime}\right)$ diperoleh nilai mogok sekolah yang mengalami trend menurun dari sesi pertama sampai sesi ketiga. Jejak data pada fase baseline (A) menurun, fase intervensi (B) menurun, dan fase baseline (A') menurun.

Pada analisis antar kondisi jumlah variabel yang diubah dalam penelitian ini adalah satu variabel yaitu mogok sekolah dengan subjek AB. Perubahan 
kecenderungan arah dan efeknya pada fase baseline (A) menunjukkan penurunan yang rendah, sedangkan pada fase intervensi (B) dan fase baseline ( $\left.A^{\prime}\right)$ mengalami penurunan yang lebih tinggi. Hal ini menunjukkan bahwa intervensi yang diberikan berpengaruh positif terhadap variabel yang diubah. Perubahan stabilitas pada fase baseline (A) termasuk dalam kategori rendah. Pada fase intervensi (B) dan fase baseline (A') termasuk dalam kategori tinggi. Perubahan stabilitas positif dari variabel (baseline A) ke variabel (intervensi B) menjadi stabil (baseline A'). Data point pada fase intervensi (B) dan baseline (A') yang berada pada rentang fase baseline (A) tidak ada, sehingga persentase data tumpang tindih adalah $0 \%$. Hal ini berarti intervensi yang diberikan sangat efektif karena $<10 \%$. Kondisi ini menunjukkan bahwa proses intervensi yang diberikan menggunakan teknik restrukturisasi kognitif dapat menurunkan mogok sekolah.

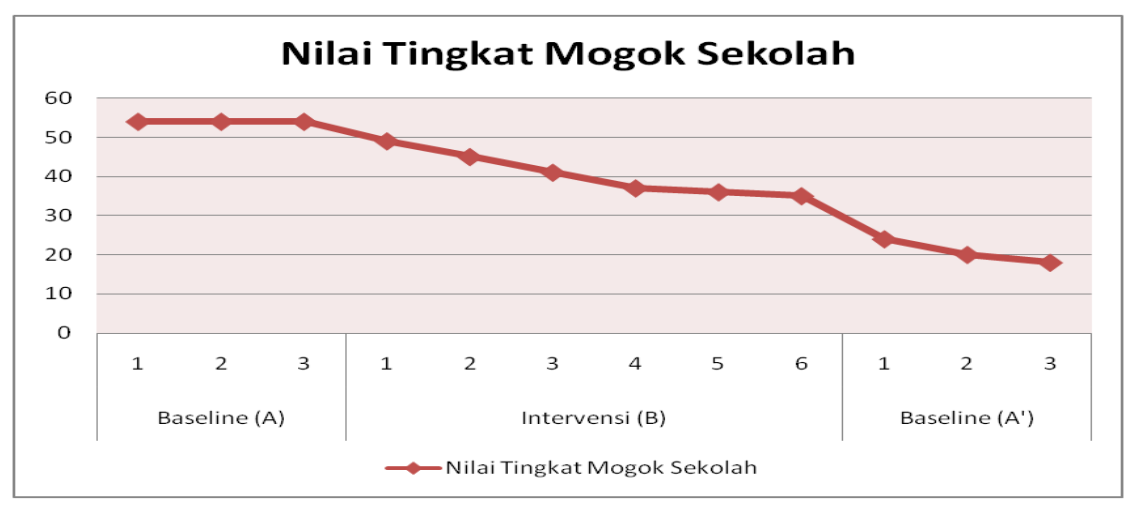

Gambar 3 Grafik Perkembangan Tingkat Mogok Sekolah Subjek FN

FN adalah siswa SMP Negeri 20 Malang yang merupakan subjek kedua dalam penelitian ini yang mengalami mogok sekolah berdasarkan hasil pengukuran awal (pre-test) dengan menggunakan skala mogok sekolah. Hasil wawancara juga menyebutkan bahwa FN enggan untuk berangkat sekolah karena ia mempunyai pikiran bahwa teman-temannya mungkin tidak menyukainya, dan apabila ia masuk sekolah teman-temannya akan berperilaku kasar terhadapnya. Pemikiran negatif yang muncul tentang sekolah itulah yang menyebabkan FN lebih memilih di rumah bermain game atau menonton televisi. 
Berdasarkan gambar 3 di atas dapat diketahui bahwa fase baseline (A) dilakukan selama tiga sesi, fase intervensi (B) dilakukan selama enam sesi, dan fase baseline ( $\mathrm{A}^{\prime}$ ) dilakukan selama tiga sesi. Pada fase baseline (A) diperoleh nilai mogok sekolah yang masih stabil pada sesi pertama dan kedua dan mengalami trend menurun pada sesi ketiga. Pada fase intervensi (B) diperoleh nilai mogok sekolah yang mengalami trend menurun dari sesi pertama sampai sesi keenam. Pada fase baseline (A') diperoleh nilai mogok sekolah yang mengalami trend menurun dari sesi pertama sampai sesi ketiga. Analisis dalam kondisi menyebutkan kecenderungan stabilitas (trend) positif dari variabel (baseline A) ke variabel (intervensi B) menjadi stabil (baseline A'). Jejak data pada fase baseline (A) menurun, fase intervensi (B) menurun, dan fase baseline ( $\left.\mathrm{A}^{\prime}\right)$ menurun.

Pada analisis antar kondisi jumlah variabel yang diubah dalam penelitian ini adalah satu variabel yaitu mogok sekolah dengan subjek FN. Perubahan kecenderungan arah dan efeknya pada fase baseline (A) menunjukkan penurunan yang rendah, sedangkan pada fase intervensi (B) dan fase baseline ( $\left.A^{\prime}\right)$ mengalami penurunan yang lebih tinggi. Hal ini menunjukkan bahwa intervensi yang diberikan berpengaruh positif terhadap variabel yang diubah. Perubahan stabilitas pada fase baseline (A) termasuk dalam kategori rendah. Pada fase intervensi (B) dan fase baseline (A') termasuk dalam kategori tinggi. Perubahan stabilitas positif dari variabel (baseline A) ke variabel (intervensi B) menjadi stabil (baseline A'). Data tumpang tindih (overlap) pada fase baseline (A) mogok sekolah memiliki batas atas 61,76 dan batas bawah 45,56. Data point pada fase intervensi (B) dan baseline ( $\mathrm{A}^{\prime}$ ) yang berada pada rentang fase baseline (A) tidak ada, sehingga persentase data tumpang tindih adalah 0\%. Hal ini berarti intervensi yang diberikan sangat efektif karena $<10 \%$. Kondisi ini menunjukkan bahwa proses intervensi yang diberikan menggunakan teknik restrukturisasi kognitif dapat menurunkan mogok sekolah.

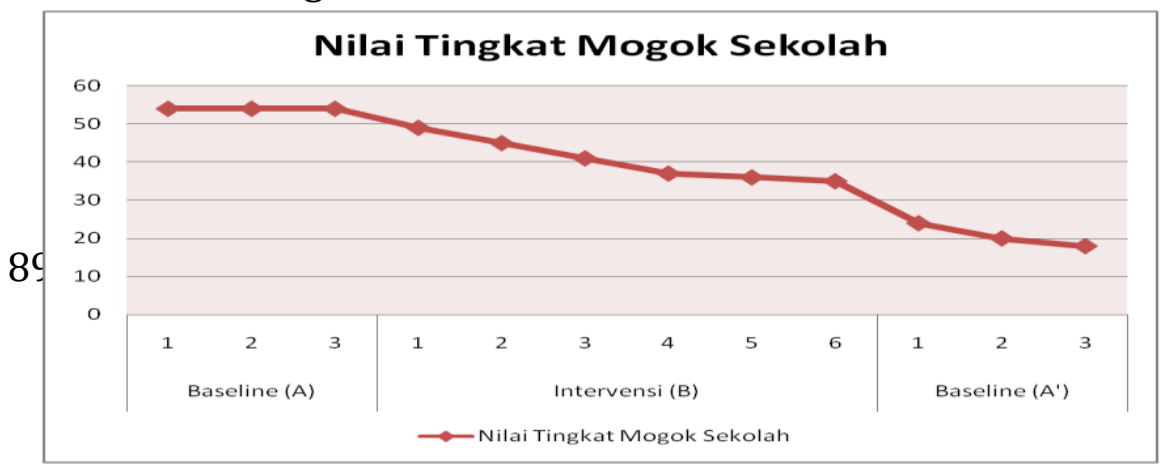


Gambar 4 Grafik Perkembangan Tingkat Mogok Sekolah Subjek SW

SW adalah siswa SMP Negeri 20 Malang yang merupakan subjek ketiga dalam penelitian ini yang mengalami mogok sekolah berdasarkan hasil pengukuran awal (pre-test) dengan menggunakan skala mogok sekolah. Hasil wawancara juga menyebutkan bahwa ketika ia akan berangkat sekolah selalu muncul pikiran negatif jika nanti di sekolah ia akan dijauhi oleh teman-temannya, SW mempunyai pikiran bahwa tidak ada teman yang suka terhadapnya. Subjek ini pernah beberapa kali dalam seminggu tidak masuk sekolah karena malas berhadapan dengan teman-teman. Namun dari pengakuan subjek SW ibunya cenderung mendukung dan meminta ia tetap masuk sekolah, sehingga SW memang berangkat sekolah namun tak jarang ketika pelajaran berlangsung ia memilih untuk tidak mengikuti kegiatan tersebut.

Berdasarkan gambar $4 \mathrm{di}$ atas dapat diketahui bahwa fase baseline (A) dilakukan selama tiga sesi, fase intervensi (B) dilakukan selama enam sesi, dan fase baseline ( $\mathrm{A}^{\prime}$ ) dilakukan selama tiga sesi. Pada fase baseline (A) diperoleh nilai mogok sekolah yang mengalami trend masih stabil pada sesi pertama dan kedua dan menurun pada sesi ketiga. Pada fase intervensi (B) diperoleh nilai mogok sekolah yang mengalam trend menurun dari sesi pertama sampai sesi keenam. Pada fase baseline ( $\mathrm{A}^{\prime}$ ) diperoleh nilai mogok sekolah yang mengalami trend menurun dari sesi pertama sampai sesi ketiga. Analisis dalam kondisi menunjukkan jejak data pada fase baseline (A) menurun, fase intervensi (B) menurun, dan fase baseline ( $\left.\mathrm{A}^{\prime}\right)$ menurun.

Pada analisis antar kondisi jumlah variabel yang diubah dalam penelitian ini adalah satu variabel yaitu mogok sekolah dengan subjek SW. Perubahan 
kecenderungan arah dan efeknya pada fase baseline (A) menunjukkan penurunan yang rendah, sedangkan pada fase intervensi (B) dan fase baseline ( $\left.\mathrm{A}^{\prime}\right)$ mengalami penurunan yang lebih tinggi. Hal ini menunjukkan bahwa intervensi yang diberikan berpengaruh positif terhadap variabel yang diubah. Perubahan stabilitas pada fase baseline (A) termasuk dalam kategori rendah. Pada fase intervensi (B) dan fase baseline (A') termasuk dalam kategori tinggi. Perubahan stabilitas positif dari variabel (baseline A) ke variabel (intervensi B) menjadi stabil (baseline A'). Hal ini menunjukkan bahwa mogok sekolah subjek $\mathrm{AB}$ mengalami penurunan. Tanda (+) menunjukkan bahwa terjadi penurunan mogok sekolah dari fase baseline (A) ke fase intervensi (B). Data tumpang tindih (overlap) pada fase baseline (A) mogok sekolah memiliki batas atas 61,76 dan batas bawah 44,9. Data point pada fase intervensi (B) dan baseline (A') yang berada pada rentang fase baseline (A) tidak ada, sehingga persentase data tumpang tindih adalah $0 \%$. Hal ini berarti intervensi yang diberikan sangat efektif karena $<10 \%$. Kondisi ini menunjukkan bahwa proses intervensi yang diberikan menggunakan teknik restrukturisasi kognitif dapat menurunkan mogok sekolah.

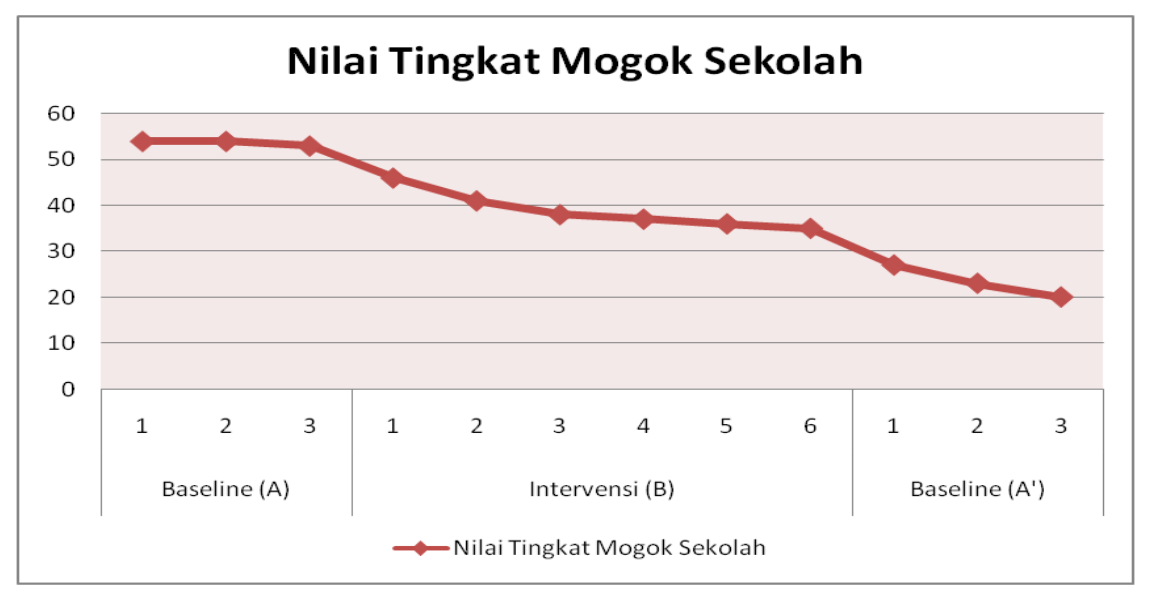

Gambar 5 Grafik Perkembangan Tingkat Mogok Sekolah Subjek DE

DE adalah siswa SMP Negeri 20 Malang yang merupakan subjek keempat dalam penelitian ini yang mengalami mogok sekolah berdasarkan hasil pengukuran awal (pre-test) dengan menggunakan skala mogok sekolah. Hasil 
wawancara juga menyebutkan bahwa penyebab DE mogok sekolah adalah ia dituduh mengambil uang kas, sehingga DE mempunyai pikiran bahwa di kelas ia tidak akan mempunyai teman, dan DE tidak akan dipercaya oleh teman sekelasnya. Dari penuturan subjek DE, semenjak itulah ia mengalami mogok sekolah, berangkat sekolahpun dipaksa oleh ibunya. Namun, akibat dari hal ini subjek DE merasa tidak betah di kelas, dan sering tidak mengikuti pelajaran di kelas tersebut.

Berdasarkan gambar $5 \mathrm{di}$ atas dapat diketahui bahwa fase baseline (A) dilakukan selama tiga sesi, fase intervensi (B) dilakukan selama enam sesi, dan fase baseline (A') dilakukan selama tiga sesi. Pada fase baseline (A) diperoleh nilai mogok sekolah trend masih stabil pada sesi pertama dan kedua kemudian menurun pada sesi ketiga. Pada fase intervensi (B) diperoleh nilai mogok sekolah yang mengalam trend menurun dari sesi pertama sampai sesi keenam. Pada fase baseline ( $\mathrm{A}^{\prime}$ ) diperoleh nilai mogok sekolah yang mengalami trend menurun dari sesi pertama sampai sesi ketiga. Analisis dalam kecenderungan stabilitas (trend) positif dari variabel (baseline A) ke variabel (intervensi B) menjadi stabil (baseline $\left.\mathrm{A}^{\prime}\right)$. Jejak data pada fase baseline (A) menurun (+), fase intervensi (B) menurun (+), dan fase baseline ( $\left.\mathrm{A}^{\prime}\right)$ menurun $(+)$.

Pada analisis antar kondisi jumlah variabel yang diubah dalam penelitian ini adalah satu variabel yaitu mogok sekolah dengan subjek DE. Perubahan kecenderungan arah dan efeknya pada fase baseline (A) menunjukkan penurunan yang rendah, sedangkan pada fase intervensi (B) dan fase baseline ( $\left.A^{\prime}\right)$ mengalami penurunan yang lebih tinggi. Hal ini menunjukkan bahwa intervensi yang diberikan berpengaruh positif terhadap variabel yang diubah. Perubahan stabilitas pada fase baseline (A) termasuk dalam kategori rendah. Pada fase intervensi (B) dan fase baseline (A') termasuk dalam kategori tinggi. Perubahan stabilitas positif dari variabel (baseline A) ke variabel (intervensi B) menjadi stabil (baseline A'). Hal ini menunjukkan bahwa mogok sekolah subjek DE mengalami penurunan. Tanda (+) menunjukkan bahwa terjadi penurunan mogok sekolah dari fase baseline (A) ke fase intervensi (B). Data tumpang tindih (overlap) pada fase baseline (A) mogok 
sekolah memiliki batas atas 61,76 dan batas bawah 45,56. Data point pada fase intervensi (B) dan baseline (A') yang berada pada rentang fase baseline (A) tidak ada, sehingga persentase data tumpang tindih adalah $0 \%$. Hal ini berarti intervensi yang diberikan sangat efektif karena $<10 \%$. Kondisi ini menunjukkan bahwa proses intervensi yang diberikan menggunakan teknik restrukturisasi kognitif dapat menurunkan mogok sekolah.

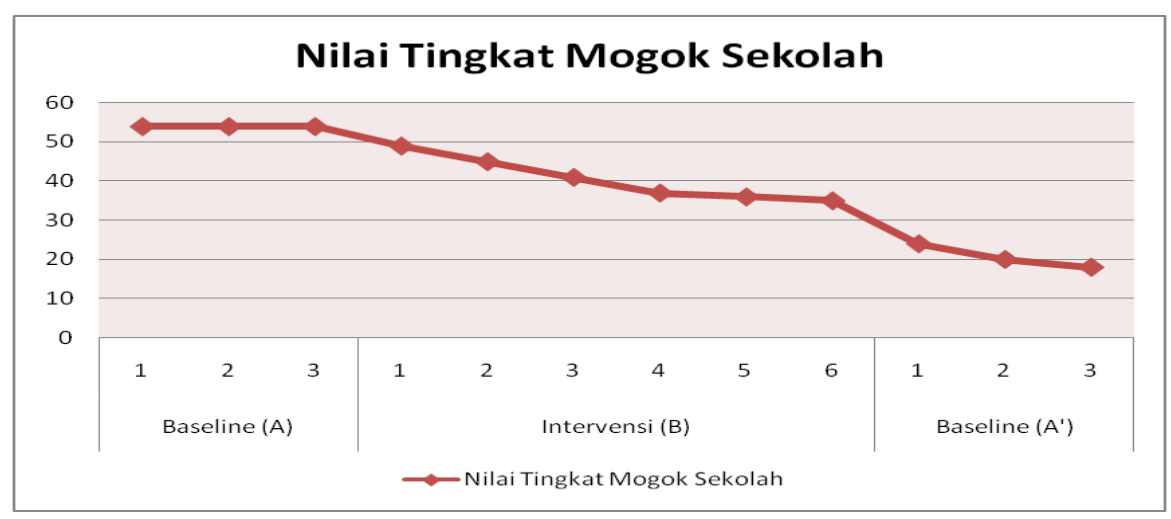

Gambar 6 Grafik Perkembangan Tingkat Mogok Sekolah Subjek RF

RF adalah siswa SMP Negeri 20 Malang yang merupakan subjek kelima dalam penelitian ini yang mengalami mogok sekolah berdasarkan hasil pengukuran awal (pre-test) dengan menggunakan skala mogok sekolah. Hasil wawancara juga menyebutkan kedua orangtua RF telah meninggal dunia. Ia tinggal bersama kakak, adik, dan juga neneknya. Dari penuturan subjek RF ia mengalami mogok sekolah karena ada pemikiran negatif yang muncul ketika ia berangkat sekolah yaitu ia tidak bisa mengikuti beberapa mata pelajaran. Ditambah lagi dari penuturan RF, ketika terdapat tugas, muncul pikiran negatif kembali bahwa ia tidak akan sanggup mengerjakan tugas tersebut. Subjek mengatakan ketiadaan kedua orangtua itu membuat pikiran negatifnya tentang masa yang akan datang seringkali muncul.

Berdasarkan gambar 6 di atas dapat diketahui bahwa fase baseline (A) dilakukan selama tiga sesi, fase intervensi (B) dilakukan selama enam sesi, dan fase baseline (A') dilakukan selama tiga sesi. Pada fase baseline (A) diperoleh nilai mogok sekolah yang mengalami trend masih stabil dari sesi pertama sampai sesi 
ketiga. Pada fase intervensi (B) diperoleh nilai mogok sekolah yang mengalami trend menurun dari sesi pertama sampai sesi keenam. Pada fase baseline (A') diperoleh nilai mogok sekolah yang mengalami trend menurun dari sesi pertama sampai sesi ketiga. Pada analisis dalam kondisi adanya kecenderungan stabilitas (trend) positif dari variabel (baseline A) ke variabel (intervensi B) menjadi stabil (baseline $\mathrm{A}^{\prime}$ ). Jejak data pada fase baseline (A) menurun (+), fase intervensi (B) menurun (+), dan fase baseline ( $\left.\mathrm{A}^{\prime}\right)$ menurun (+). Analisis antar kondisi jumlah variabel yang diubah dalam penelitian ini adalah satu variabel yaitu mogok sekolah dengan subjek RF. Perubahan kecenderungan arah dan efeknya pada fase baseline (A) menunjukkan penurunan yang rendah, sedangkan pada fase intervensi (B) dan fase baseline (A') mengalami penurunan yang lebih tinggi.

Hal ini menunjukkan bahwa intervensi yang diberikan berpengaruh positif terhadap variabel yang diubah. Perubahan stabilitas pada fase baseline (A) termasuk dalam kategori rendah. Pada fase intervensi (B) dan fase baseline (A') termasuk dalam kategori tinggi. Perubahan stabilitas positif dari variabel (baseline A) ke variabel (intervensi B) menjadi stabil (baseline A'). Hal ini menunjukkan bahwa mogok sekolah subjek RF mengalami penurunan. Tanda (+) menunjukkan bahwa terjadi penurunan mogok sekolah dari fase baseline (A) ke fase intervensi (B). Data tumpang tindih (overlap) pada fase baseline (A) mogok sekolah memiliki batas atas 62,1 dan batas bawah 45,9. Data point pada fase intervensi (B) dan baseline ( $\mathrm{A}^{\prime}$ ) yang berada pada rentang fase baseline (A) tidak ada, sehingga persentase data tumpang tindih adalah $0 \%$. Hal ini berarti intervensi yang diberikan sangat efektif karena $<10 \%$. Kondisi ini menunjukkan bahwa proses intervensi yang diberikan menggunakan teknik restrukturisasi kognitif dapat menurunkan mogok sekolah.

Selain pengukuran melalui observasi pada setiap fase baseline (A), intervensi (B), dan fase baseline (A') juga dilakukan pengukuran dengan menggunakan skala mogok sekolah. Adapun hasil pengukuran menggunakan skala mogok sekolah sebelum dan sesudah intervensi. 
Tabel 2 Hasil Pengisian Instrumen Skala Mogok Sekolah Sebelum dan Sesudah Intervensi

\begin{tabular}{ccc}
\hline Konseli & $\begin{array}{c}\text { Sebelum } \\
\text { Intervensi }\end{array}$ & $\begin{array}{c}\text { Sesudah } \\
\text { Intervensi }\end{array}$ \\
\hline $\mathrm{AB}$ & 62 & 35 \\
\hline $\mathrm{FN}$ & 58 & 34 \\
\hline $\mathrm{SW}$ & 57 & 34 \\
\hline $\mathrm{DE}$ & 56 & 38 \\
\hline $\mathrm{RF}$ & 53 & 36
\end{tabular}

Pada tabel di atas memaparkan perolehan skor intrumen skala mogok sekolah sebelum dan sesudah intervensi yang mana dapat dilihat bahwa masingmasing siswa mengalami penurunan mogok sekolah. Subjek AB sebelum intervensi mendapatkan skor 62 dan setelah intervensi mengalami penurunan menjadi 35 . Subjek FN sebelum intervensi mendapatkan skor 58 dan setelah intervensi mendapat skor 34. Subjek SW sebelum intervensi mendapat skor 57 dan setelah intervensi mendapatkan skor 34. Subjek DE sebelum intervensi mendapatkan skor 56 dan setelah intervensi mendapatkan skor 36. Berdasarkan penjabaran adanya penurunan skor tersebut bermakna bahwa perubahan yang dialami siswa mengindikasikan bahwa intervensi menggunakan teknik retrukturisasi kognitif dapat menurunkan mogok sekolah siswa SMP.

Analisis data selanjutnya yang akan dipaparkan adalah analisis statistik. Analisis yang digunakan adalah uji wilcoxon matched-pairs signed-ranks test dengan melibatkan hasil skor dari pre-test dan post-test pengisian skala mogok sekolah sebelum dan sesudah intervensi dengan teknik restrukturisasi kognitif. Hasil skor sebelum dan sesudah intervensi kelima subjek yaitu AB, FN, SW, DE, dan RF dapat dilihat pada tabel 4.3. Analisis statistik ini dilakukan untuk menguji hipotesis yaitu pengaruh secara langsung maupun tidak langsung dari variabelvariabel dalam penelitian.

Tabel 3 Hasil Uji Wilcoxon Matched-Pairs Signed-Ranks Test

Post_Test - Pre_Test 


\begin{tabular}{lr}
$\begin{array}{lr}\text { Z } \\
\text { Asymp. Sig. (2- } \\
\text { tailed) }\end{array}$ & $-2,023^{\mathrm{b}}$ \\
\hline
\end{tabular}

Temuan yang menunjukkan teknik restrukturisasi kognitif memiliki keterkaitan dengan mogok sekolah adalah teknik restrukturisasi bertujuan untuk membantu mengubah pandangan negatif menjadi positif pada kegagalan yang dialaminya (Meinchenbaum 1997). Kelima subjek yaitu AB, FN, SW, DE, dan RF mempunyai pandangan negatif terhadap sekolah dengan berbagai macam penyebab. Sehingga, ketika diberikan bantuan dengan teknik ini kelima subjek tersebut dapat merubah atau menstruktur kembali pandangan yang semula negatif menjadi positif atas permasalahan yang sedang dialaminya. Meinchenbaum (1997) menyatakan terdapat tiga proses dalam pelaksanaan teknik restrukturisasi kognitif, yang mencakup observasi diri, self-talk, dan belajar keterampilan baru.

Observasi diri, yaitu proses pengubahan pola berfikir terdiri atas cara belajar subjek bagaimana mengobservasi tingkah laku. Pada proses pertama ini, peneliti meminta kelima subjek untuk mengobservasi diri mereka sendiri, seperti yang diungkapkan oleh subjek $\mathrm{AB}$, ia mengalami mogok sekolah ketika mendapat teguran dari guru dan tugas menumpuk. Subjek FN mengalami mogok sekolah karena diganggu dengan teman-teman di kelas bahkan ketika ia pergi ke kamar mandi pasti terdapat barangnya yang disembunyikan oleh teman-teman. Subjek SW mengalami mogok sekolah karena merasa sering diabaikan oleh teman-teman di kelas, sedangkan subjek DE yang dituduh mengambil uang kas sehingga menyebabkan ia malas masuk sekolah, dan RF yang mengalami mogok sekolah karena takut tidak mampu mengikuti pelajaran.

Melakukan dialog internal baru (self-talk), yaitu subjek belajar untuk memperhatikan tingkah laku yang mengganggunya dan ia harus membuat suatu rantai behavioral baru. Pada proses ini peneliti memberikan lembar tugas yang berisi kejadian penyebab mogok sekolah, pikiran negatif yang muncul, pikiran negatif tersebut di coping lalu akan muncul pikiran positif. Seperti skema pikiran 
dari subjek FN, penyebab ia mogok sekolah yaitu diganggu dengan teman sehingga menyebabkan ia kesal. Pikiran negatif yang muncul adalah "apakah nanti temanteman akan mengangguku?", kemudian dilakukan coping thought "tidak, semoga nanti mereka tidak mengangguku.", lalu muncul pikiran positifnya (positive selfstatement) yaitu "aku tetap harus masuk sekolah, dan biarkan apa yang akan terjadi nanti."

Belajar ketrampilan baru, yaitu mengajarkan subjek untuk mempelajari pemecahan yang efektif dan dipraktekkan dalam kehidupan nyata. Pada proses ini peneliti mengajarkan masing-masing subjek untuk dapat mengcoping sehingga akan muncul pikiran positif atau positive self-statement yang nantinya dapat mengubah pandangan subjek yang semula enggan untuk masuk sekolah menjadi mau berangkat sekolah dengan pikiran yang positif.

Berdasarkan paparan di atas, dapat diketahui adanya keterkaitan antara mogok sekolah yang ditemui pada saat penelitian dengan teknik restrukturisasi kognitif. Adapun penelitian sebelumnya yang menunjuang yaitu teknik restrukturisasi kognitif efektif untuk mengurangi gangguan penyesuaian pada remaja (Safithry 2015). Rahmawati (2016) juga menemukan bahwa teknik restrukturisasi kognitif efektif untuk menurunkan stres akademik siswa. Muthmainah (2012) menggunakan teknik restrukturisasi kognitif untuk menurunkan Negative Automatic Thoughts. Hasil penelitiannya menunjukkan bahwa teknik restrukturisasi kognitif efektif untuk menurunkan Negative Automatic Thoughts. Kholidah \& Alsa (2012) juga menemukan bahwa berpikir positif efektif untuk menurunkan stres psikologis (Saputra, 2015), juga menggunakan teknik restrukturisasi kognitif untuk menangani prokrastinasi akademik siswa SMK yang hasilnya teknik tersebut dapat menurunkan prokrastinasi akademik siswa SMK.

Dari beberapa hasil penelitian di atas dapat dikatakan pula bahwa penelitian teknik restrukturisasi kognitif efektif untuk menurunkan mogok sekolah. Hal ini berdasarkan temuan peneliti pada saat melakukan penelitian 
diantara lain subjek penelitian dapat menunjukkan perilaku mogok sekolah yang menurun diantaranya subjek mampu bergabung dengan teman di kelas dan ikut bermain bersama, selain itu subjek dapat lebih memperhatikan ketika guru berada di kelas. Berdasarkan hasil pengisian lembar kerja juga menunjukkan bahwa subjek mampu menerapkan teknik restrukturisasi kognitif ini untuk mengatasi masalah mogok sekolah. Pengisian lembar tugas tersebut menjadi salah satu alternatif untuk melihat perubahan pikiran subjek yang semula negative dapat di coping sehingga memunculkan positife self-statement dalam dirinya.

\section{Simpulan}

Penelitian ini menguji keefektifan teknik restrukturisasi kognitif untuk menurunkan mogok sekolah siswa SMP dengan rancangan penelitian single subject design dan bentuk rancangan A-B-A. Hasil analisis visual dengan metode split middle menunjukkan bahwa pada fase baseline (A) masing-masing subjek masih berada pada kondisi yang sama, fase intervensi (B) masing-masing subjek berada pada kondisi yang sudah stabil, dan fase baseline (A') masing-masing subjek sudah menunjukkan perbedaan. Oleh karena itu, dapat disimpulkan bahwa terdapat perbedaan dari sebelum diberikan intervensi dengan sesudah diberikan intervensi menggunakan teknik restrukturisasi kognitif untuk menurunkan mogok sekolah siswa SMP dengan kategori penurunan tingkat mogok sekolah setiap subjek berbeda-beda. 


\section{DAFTAR PUSTAKA}

Ampuni, Sutarimah, and Budi Andayani. 2007. "Memahami Anak Dan Remaja Dengan Kasus Mogok Sekolah: Gejala, Penyebab, Struktur Kepribadian, Profil Keluarga, Dan Keberhasilan Penanganan." Jurnal Psikologi 34(1):5575-75.

Bond, P. W., and W. Dryden. 2004. Handbook of Brief Cognitive Behavior Therapy: England: John Wiley \& Sons Ltd.

Brill, L. D. 2009. "School Refusal: Characteristics, Assessment, and Effective Treatment: A Child and Parent Perspective." Doctoral Dissertation, Philadelphia College of Osteopathic Medicine), Philadelphia.

Charlina, T. Riva. 2013. "Pengaruh Behavior Modification Terhadap Perubahan Frekuensi Perilaku Seksual Pada Remaja Di Kota Batu." Thesis, Universitas Muhammadiyah Malang, Malang.

Chomariah, Nurul. 2008. Aku Sudah Gede (Ngobrolin Pubertas Buat Remaja Islam). Solo: Samudera.

Cormier, S., and S. P. Nurius. 2009. Interviewing and Change Strategies for Helper. USA: Brooks/Cole.

Davison, G. C., M. N. John, and M. K. Ann. 2006. Psikologi Abnormal. Jakarta: Raja Grafindo Persada.

Hurlock, Elizabeth Bergner. 2000. Perkembangan Anak. Jakarta: Erlangga.

Kearney, Christoper A., and Anne Marie. Albano. 2007. When Children Refuse School. First Edition. New York: Oxford Press, Inc.

Kearney, Christoper A., Gillian Chapman, and L. Caitlin Cook. 2005. "School Refusal Behavior in Young Children." International Journal of Behavioral Consultation and Therapy 1 No 3.

Kholidah, Enik Nur, and Asmadi Alsa. 2012. "Berpikir Positif Untuk Menurunkan Stres Psikologis." Jurnal Psikologi 39(1):67-75-75.

Meinchenbaum, D. 1997. Cognitive-Behavior Modification: An Integrative Approach. New York: Plenum Press.

Muthmainah. 2012. "Keefektifan Teknik Cognitive RestructuringI Untuk Menurunkan Negative Authomatic Thoughts Pada Siswa SMA." Master Thesis, Universitas Negeri Malang, Malang.

Rahmawati, Weni Kurnia. 2016. "Efektivitas Teknik Restrukturisasi Kognitif Untuk Menangani Stres Akademik Siswa." JKI (Jurnal Konseling Indonesia) 2(1):1521.

Runtukahu, T. 2013. Analisis Perilaku Terapan Untuk Guru. Yogyakarta: Ar-Ruzz Media.

Safithry, Esty Aryani. 2015. "Restrukturisasi Kognitif Untuk Mengurangi Gangguan Penyesuaian Pada Remaja." Pedagogik Jurnal Pendidikan 10 No. 2.

Saputra, Wahyu N. E. 2015. "Perbandingan Prokrastinasi Akademik Siswa SMK Melalui Penerapan Teknik Cognitive Restructuring Dan Cognitive Defusion." Master Thesis, Universitas Negeri Malang, Malang.

Sukmadinata, Nana Syaodih. 2005. Metode Penelitian Pendidikan. Bandung: Remaja 
Rosdakarya.

Sunanto, J., Takeuchi, K., and H. Nakata. 2005. Pengantar Penelitian Dengan Subjek Tunggal. Jakarta: Center For Research on International in Educational Development: University of Tsukuba.

Suseno, Armytalia Nur. 2015. "Penolakan Sekolah (School Refusal) Pada Siswa Sekolah Dasar." Skripsi, Universitas Negeri Semarang, Semarang.

Seetzer, N, Salzhauer, A. (2006). Understanding School Refusal. www.aboutkids.org. 